\title{
UMA LEITURA SOBRE O INTELECTUAL ORGÂNICO EM GRAMSCI
}

\author{
A READING ON THE ORGANIC INTELLECTUAL IN GRAMSCI \\ UNA LECTURA ACERCA DEL INTELECTUAL ORGÁNICO EN GRAMSCI
}

Rodrigo Diaz de Vivar y Soler*

\begin{abstract}
RESUMO
Este texto apresenta algumas reflexões sobre o estatuto do intelectual orgânico em Gramsci. A partir de um olhar voltado para alguns textos desse pensador e comentadores, recolhemos os indicativos do comprometimento dessa figura com a sociedade num diálogo aberto entre a cultura e a hegemonia, possibilitando, dessa maneira, a emancipação das massas. A questão levantada por Gramsci consiste na tarefa de percebermos o intelectual orgânico como um personagem e a cultura como um processo sempre em expansão. Assim, o intelectual orgânico como raison d'être é o sujeito que, atrelado ao sistema cultural, procura pensar questôes polêmicas e dirigir uma prática que esteja necessariamente atrelada aos problemas sociais modernos. Esse personagem está preso na organização da cultura, agindo sempre em relação, e esse agir se efetiva numa proposta de transformação histórica na qual as velhas ortodoxias cedem espaço para novas inquietaçóes e dilemas.
\end{abstract}

Palavras-chave: Intelectual orgânico. Gramsci. Cultura.

\begin{abstract}
This paper presents some reflections of the organic intellectual in Gramsci thought's. From a reading fixed on some texts of this thinker and commentators gathered indicative of the commitment of this figure with the company in an open dialogue between culture and hegemony, enabling this way, the emancipation of the people. The question developed by Gramsci is the task of realizing the organic intellectual as a character and culture as a process always expanding. Thus, the organic intellectual raison d'être is the subject who tries to think controversial issues and to direct a practice that is necessarily linked to modern social problems. This character is stuck in the culture of the organization always acting with respect, and that act effectively in an historic transformation proposal in which the old orthodoxies give way to new concerns and dilemmas.
\end{abstract}

Keywords: Organic intellectual. Gramsci. Culture.

\footnotetext{
Texto recebido em 23 de março de 2014 e aprovado para publicação em 12 de novembro de 2015.

Doutorando em Filosofia pela Unisinos, mestre em Psicologia pela UFSC, professor do Centro Universitário Estácio de Sá (SC), bacharel em Psicologia pela Unesc. E-mail: diazsoler@gmail.com.
} 


\section{RESUMEN}

Este artículo presenta algunas reflexiones sobre el estatuto del intelectual orgánico en Gramsci. Desde una mirada enfocada en algunos textos de este pensador y otros comentaristas, se reunieron los indicativos del compromiso de esta figura en un diálogo abierto entre la cultura y la hegemonía, posibilitando de esta manera, la emancipación de las masas. La cuestión planteada por Gramsci es la tarea de percibir el intelectual orgánico como un personaje y a la cultura como un proceso siempre en expansión. Así, el intelectual orgánico como raison d'être es el sujeto que, vinculado al sistema cultural, intenta pensar cuestiones polémicas y llevar a cabo una práctica que esté necesariamente conectada con los problemas sociales modernos. Este personaje está prisionero en la organización de la cultura, actuando siempre en relación, y ese obrar se realiza en una propuesta de transformación histórica en la que las viejas ortodoxias dan paso a nuevas inquietudes y dilemas.

Palabras clave: Intelectual orgánico. Gramsci. Cultura.

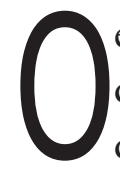

estatuto do intelectual orgânico leva em conta algumas singularidades que o distanciam tanto do conservadorismo do intelectual tradicional ${ }^{1}$ quanto do dogmatismo do intelectual revolucionário. ${ }^{2}$ Queremos dizer com isso que, se por um lado, as limitaçóes de um intelectual clássico dizem respeito ao fato de que as suas reflexões são comprometidas com os interesses da classe dominante. Por outro, a limitação do intelectual revolucionário efetiva-se na crença de que é preciso conscientizar as massas visando ao fim do processo de alienação por meio da expropriação da produção e da conquista do Estado. Como contrapartida a esses estatutos, encontramos a proveniência do intelectual orgânico.

Como um dos fundadores do Partido Socialista Italiano, Gramsci, durante toda a sua trajetória política, procurou lutar contra o fascismo. As experiências de criação dos jornais militantes L'Ordine Nuovo e L'Unità são imprescindíveis para esboçarmos uma compreensão em torno dessas atividades políticas. Ao debruçarmo-nos sobre a leitura do texto O Movimento do Ordine Nuovo (Gramsci, 1978b), localizamos os indicativos de uma renovação do movimento socialista italiano.

Uma dessas características presentes na renovação do movimento socialista italiano diz respeito à própria concepção de política. A política precisa ser

\footnotetext{
Por intelectual tradicional Gramsci (1997) entende aqueles tipos de sujeitos que se ocupam somente com suas funções descritivas sem estabelecer qualquer tipo de compromisso ou responsabilização com a sociedade na qual vivem. Esses seriam, portanto, os intelectuais orientados pela estruturação e difusão de perspectivas ideológicas conservadoras fundamentadas em discursos como o da neutralidade, por exemplo.

2 Já o intelectual revolucionário faz parte da ortodoxia marxiana, e sua proveniência remonta à passagem do final do século XIX e as primeiras duas décadas do século XX, época de ouro do assim chamado positivismo marxista, descrito por Gruppi (1980) como uma epistemologia que procurava instruir as massas, levando à posterior derrocada do capital e a instauração da ditadura do proletariado.
} 
concebida não como um instrumento discursivo que objetiva o consenso, mas como uma estratégia que objetiva a conquista e a manutenção do poder por parte dos trabalhadores e camponeses. Nesse sentido, ela deve ser caracterizada por suas ações, e o político, concebido por Gramsci (1978b) como ser em movimento, não deve ser confundido com o cientista nem com o filósofo, mas sim como um agente transformador da sociedade. Em outras palavras, trata-se de dizer o seguinte: o político não interpreta a realidade, mas atua efetivamente, exercendo um papel social que é sempre crítico, segundo Bianchi (2009). Essa leitura nos permite pensar em uma estreita relação do político com o intelectual orgânico no que diz respeito à função desempenhada por ambos nos mecanismos institucionais, como os partidos políticos, as universidades e as fábricas. Essa correlação desembocará na efetivação de um estatuto comprometido com a construção de novos valores. Da mesma maneira que o político, o intelectual orgânico responsabiliza-se não somente por pensar as bases de atuação do socialismo, mas por participar efetivamente em cada setor, sempre procurando despertar a consciência coletiva das classes oprimidas pelo capitalismo, pois o intelectual orgânico atua internamente ao sistema, buscando destituir ideologias em nome de uma nova concepção cultural emancipadora das massas.

Mas qual seria efetivamente o papel da ideologia na emancipação popular? Para Gramsci (1978c), a adesão ou não de um grupo a determinada ideologia efetivase não pela vontade ou desejo de uma classe sobre a outra, mas pelos contextos e modos de pensar presentes em determinada sociedade. Isso significa que, para haver realmente ideologia, é necessária a existência de condições materiais e históricas bastantes para a efetivação de um discurso e a sua transformação em uma prática. Por exemplo, o fascismo como força ideológica somente veio a tornar-se uma força política por conta do enfraquecimento da esquerda italiana perante as demais nações europeias. Ele surgiu como elemento de propaganda para unificar os italianos em torno de um ideal racionalista, altamente autoritário e conservador rechaçando qualquer indicativo de uma cultura realmente popular e crítica.

É evidente que uma construção de massa de tal gênero não pode dar-se "arbitrariamente", à volta de qualquer ideologia, pela vontade formalmente construtiva de uma personalidade ou de um grupo que se prolonga pelo fanatismo das próprias convicções filosóficas ou religiosas. A adesão de massa a uma ideologia ou a não adesão é o modo como se verifica a crítica real da racionalidade e da historicidade dos modos de pensar. As construçóes arbitrárias são mais ou menos rapidamente eliminadas da competição histórica, ainda quando, por vezes, por uma combinação de circunstâncias imediatas favoráveis, conseguem gozar de uma certa popularidade, enquanto as construçóes que correspondem às exigências de um período histórico complexo e orgânico acabam sempre por impor-se e prevalecer mesmo atravessando muitas fases intermediárias em que a sua afirmação se dá apenas em combinações mais ou menos bizarras e heteróclitas (Gramsci, 1978d, p. 37). 
Tal qual essa citação sugere, o confronto contra as formas de dominação ocorre no campo ideológico; não obstante a ideologia não ser um falseamento ou uma ocultação da realidade, mas uma produção superestrutural. Gramsci percebe a importância desse conceito quando lê o prefácio de Crítica da economia política. Nesse texto, Marx (1982) adota uma postura revolucionária em relação à ideologia, explicitando a importância de se criticarem os domínios da superestrutura, pois as grandes batalhas ocorrem nesse terreno.

Nesse sentido, embora o proletariado deva apropriar-se dos modos de produção, é imprescindível travar uma luta contra as ideologias. De acordo com Secco (2009), a importância da superestrutura significa mais que um deslocamento. $\mathrm{Na}$ realidade, indica uma contextualização do marxismo com base na definição de que esse saber é uma filosofia da práxis. Ou seja, se infraestrutura e superestrutura são uma dialetização, uma não pode existir sem a outra. $O$ duplo aberto por esse processo pode ser precisado com a constatação de que a superestrutura se sobrepõe à infraestrutura conforme as relações de produção avançam sobre forças produtivas materiais. Assim, a superestrutura é a estratificação de aparatos ideologicamente construídos segundo os desdobramentos do sistema capitalista.

Se a superestrutura é uma estratificação, ela tem um sentido histórico, e Gramsci (1978d) realiza o resgate desse conceito afirmando que ela provém da corrente filosófica conhecida como sensismo. Maurice de Candillac foi o primeiro a conceber o conhecimento como um produto oriundo exclusivamente das sensaçôes. Esse filósofo considerava que o exercício racional somente era possível mediante a relação do indivíduo com o mundo. Por conta disso, a ideologia iria se aproximar da realidade e do dogmatismo religioso, permanecendo atrelada a essa concepção limitada. Desse modo, Gramsci (1978d) problematiza a noção de ideologia, opondo-lhe o conceito de práxis como superação das contradições existentes.

A filosofia da práxis representa a superação de todas as formas de ideologia. O grande equívoco dos estudiosos marxistas, segundo Gramsci (1978d), foi subordinar as ideologias aos problemas de infraestrutura, como se os modos de produção tivessem mais relevância do que o aprofundamento dos valores ideológicos, acarretando três consequências diretas: a primeira seria a crença de que os elementos estruturais dominam as ideologias. A segunda, a afirmação de que as soluções políticas não são suficientes para a transformação da realidade sem a tomada dos modos de produção. Por fim, estabelecer a crença de que a ideologia é simplesmente uma representação da realidade.

A intenção de Gramsci (1978d) é distanciar-se dessas concepções limitadas. E para alcançar tal objetivo, ele procura desmembrar a ideologia em duas partes: 
de um lado, as concepções ideológicas orgânicas, e de outro lado, as ideologias arbitrárias. Enquanto as primeiras têm como princípio a organização e o fortalecimento das massas, atuando diretamente na conscientização, as segundas limitam-se apenas à convicção e difusão de crenças individualistas, reduzindo todo o conjunto complexo de afirmações com base numa universalidade.

É preciso, portanto, distinguir entre ideologias historicamente orgânicas, que são necessárias a uma certa estrutura, e ideologias arbitrárias, racionalistas, "queridas". Enquanto historicamente necessárias, têm uma validade que é validade "psicológica", "organizam" as massas humanas, formam o terreno em que os homens se movem, adquirem consciência da sua posição, lutam etc. Enquanto "arbitrárias", não criam outra coisa senão "movimentos" individuais, polêmicas, etc. (não são completamente inúteis nem mesmo estas, porque são como o erro que se contrapõe à verdade e a afirma) (Gramsci, 1978d, p. 65).

O fato é que esse efeito da ideologia possibilita uma nova interpretação do e para o marxismo presente na formação de consciências políticas. Nesse sentido, o problema detém-se quase que exclusivamente sobre a superestrutura e os modos de articulação presentes em práticas que devem possibilitar a emancipação cultural dos sujeitos. Se existem uma ciência e uma cultura comprometidas com os interesses burgueses, deve existir igualmente, na outra ponta dessa relação dialética, um espaço para a insurreição de estratégias que intensificam e massificam a cultura, criando, dessa maneira, a condição necessária para o aparecimento de uma atividade intelectual debitária dos princípios da filosofia da práxis.

Com base nessa perspectiva, podemos compreender efetivamente que, enquanto o marxismo ortodoxo percebe a luta de classes como instrumento de transformação dos modos de produção, Gramsci (1978d) interessa-se em pensar a realidade a partir do movimento intensificado pelo bloco histórico cujo componente fundamental é a superestrutura. Em Alguns problemas para o estudo da Filosofia da Práxis (Gramsci, 1978a) e Problemas do materialismo histórico (Gramsci, 1978d), ele articula com precisão o papel da superestrutura no contexto da sociedade capitalista. Vejamos como é analisado esse aspecto em cada um desses textos.

Em relação a Alguns problemas para o estudo da filosofia da práxis (Gramsci, 1978a), observa-se não uma tentativa de deciframento da escritura marxista, tampouco o comentário eloquente acerca de dados biográficos sobre os seus fundamentos, mas a elaboração de uma reflexão sobre as condições de possibilidades do marxismo no início do século XX. O que está em jogo nessa leitura singular são as concepções de mundo às quais o materialismo histórico 
e dialético está atrelado e a necessidade de se instrumentalizar uma retomada dessa visão mundo. A palavra alemã Weltanschauung designa o posicionamento adotado por Marx em relação ao materialismo como uma ciência-ação (Gramsci, 1978a). Todavia essa palavra parece ter sido esquecida pelos comentadores de seus trabalhos, faltando-lhes justamente compreender que a filosofia da práxis é, antes de tudo, um compromisso firmado entre o intelectual e a sociedade. De acordo com essa perspectiva, não existe neutralidade, e, consequentemente, toda atividade intelectual está comprometida com algum valor, com algum ethos.

Essa leitura implica o caráter crítico pelo qual Gramsci (1978a) aborda os rumos tomados pelo marxismo depois de Marx. De acordo com sua leitura, enquanto Lênin manteve-se fiel ao compromisso presente na visão original dos conceitos marxianos, outros procuraram enxergar em Marx apenas o seu lado filosófico e econômico, distanciando-o da realidade social e da emancipação das massas pela criação de uma série de dogmas que dificultavam a atualização de conceitos como luta de classes e infraestrutura, por exemplo.

No pano de fundo desse panorama, encontramos o confronto entre as concepções de intelectual sedimentadas pelo conservadorismo e pela insurreição revolucionária. Se, por um lado, a leitura dos textos marxianos realizada por ideólogos burgueses como Bergson e Croce representa a perpetuação da fraseologia especulativa que contamina o contexto histórico e político do materialismo histórico e dialético, por outro, a ortodoxia intensificou a prática de um populismo vulgar e deficitário conceitualmente, favorecendo a criação de um dogmatismo e não de uma doutrina comprometida com a realidade.

A superação dessa encruzilhada na qual encontrava-se o marxismo dependia de uma nova leitura tanto teórica quando prática. Quando Gramsci (1978a) afirma que o marxismo é a filosofia da práxis, acaba por tornar contemporâneo o pensamento de Marx, entendendo que se trata de uma atividade filosófica altamente inovadora, crítica e ativa. Soma-se a isso o fato de que a práxis representa para ele um acontecimento sem precedentes. A fecundidade, o fortalecimento e a ampliação de tal acontecimento não é fruto da construção argumentativa de conceitos, muito menos da leitura hermenêutica dos textos marxianos, mas seria, antes de qualquer coisa, uma potencialização cultural que favorece a participação popular nos momentos em que ocorre a transformação social.

Nesse sentido, a práxis não é um receituário, tampouco uma futurologia, não sendo possível pensá-la com base em etapas ou em transições econômicas, mas sim uma luta que acontece no cotidiano da sociedade. Essa luta, por sua vez, está inscrita numa proposta crítica de atuação entendida aqui como uma relação social e não como uma prática burocrática e partidária. Encontramos, portanto, 
para além da importância dispensada por Gramsci em relação ao conceito de superestrutura, uma ampliação da noção de prática política pensada com base numa perspectiva crítica e também ética. Dessa forma, podemos realizar a leitura do texto Problemas do materialismo histórico (Gramsci, 1978d), encontrando, logo no seu início, as seguintes palavras:

É preciso destruir o preconceito muito difundido de que a filosofia é qualquer coisa de muito difícil pelo fato de ser atividade intelectual própria de uma determinada categoria de cientistas especializados ou de filósofos profissionais e sistemáticos. É preciso, portanto, demonstrar preliminarmente que todos os homens são "filósofos", definindo os limites e as características desta "filosofia espontânea", própria de "toda a gente", isto é, da filosofia contida: 1) na própria linguagem, que é um conjunto de noçōes e de conceitos determinados e não só de palavras gramaticalmente vazias de conteúdo; 2) no senso comum e no bom senso; 3) na religião popular e, portanto, também em todo o sistema de crenças, superstições, opiniões, modos de ver e de atuar que se esboçam naquilo que geralmente se chama folclore (p. 21).

À proposta política presente nessa reflexão corresponde a desconstrução da noção clássica de intelectual. É contra essa ideologia que se deve lutar levando-se em conta que a atividade intelectual está presente nisso que se chama de filosofia espontânea, ou seja, nas práticas culturais chamadas pejorativamente de folclore. De certa maneira, Gramsci (1978d) incita-nos a compreender os motivos pelos quais somos constituídos também por esses saberes populares e que estes, por sua vez, indicam o estatuto do intelectual orgânico como organizador da cultura.

A provocação, por parte de Gramsci (1978d), de que todos os homens são filósofos abre espaço para que o intelectual orgânico participe conscientemente das questôes que envolvem a sua realidade atuando sempre criticamente no interior das estruturas do Estado. Nesse sentido, a proposta seria a de conceituar os elementos estratégicos para a construção de um novo estatuto para o intelectual comprometido efetivamente com a realidade em que ele está inserido. Todavia esse comprometimento não está contaminado pelo positivismo histórico, muito menos pelo conservadorismo burocrático dos partidos socialistas. O marxismo, como práxis, significa a emergência e o olhar crítico sobre a hegemonia e a cultura. Logo, a prática do intelectual orgânico funciona internamente às estruturas. Por meio da atuação nos aparelhos ideológicos, o intelectual orgânico deve lutar para que existam condições para a produção da hegemonia, que, no seu caso, refletese na potencialização da cultura proveniente de saberes populares, por exemplo, o folclore.

Em relação à hegemonia, pode-se afirmar que ela é um instrumento eficaz porque potencializa as ideologias, transformando o conhecimento e dando-lhe 
uma amplitude que escapa aos interesses burgueses. Mas, qual é, especificamente, a relação da hegemonia com a função crítica exercida pelo intelectual? A resposta a essa pergunta encontra-se delineada na conclusão de que, durante o exercício da atividade política, o intelectual procede uma remontagem de sua prática, procurando superar o economicismo-corporativista por meio da profusão de novas experiências que valorizam cada vez mais a emancipação das massas. Isso é crucial para afastar Gramsci do marxismo ortodoxo, pois, enquanto este último aproxima a hegemonia da noção de ditadura do proletariado, Gramsci a percebe como uma dinâmica aberta que se desenvolve no terreno da superestrutura.

Conforme apontou-se anteriormente, o marxismo ortodoxo compreende que a superação das ideologias somente é possível por meio da ação revolucionária. Ou seja, de nada adianta instituir novos discursos sem que haja uma intervenção material capaz de transformar a realidade por meio da tomada dos modos de produção. Gramsci (2004) vai além dessa limitação no momento em que entende a atividade filosófica como uma concretização da hegemonia a partir de uma articulação entre teoria e ação política. Para ele, a única filosofia possível é a filosofia histórica. Nesse sentido, a atividade filosófica deve deixar de lado toda metafísica para debruçar-se sobre a materialidade presente nas relações sociais. Dessa maneira, podemos destacar que, se por um lado, toda filosofia é história, por outro, toda filosofia tem um sentido político. E no caso específico do marxismo, esse sentido corresponde à invenção da práxis como estratégia que objetiva não somente a reflexão, mas também a transformação da realidade. É imbricada nessa ideia de transformação que a hegemonia se encontra, uma vez que ela significa a construção de uma nova sociedade organizada segundo os critérios de uma ampla coalizão política. Isto é, por significar uma transformação global, a hegemonia tem consequências diretas não somente sobre a economia, mas sobre as superestruturas.

É essa conexão de teoria e prática que permite a Gramsci afirmar que a teoria e a realização da hegemonia do proletariado [...] têm um grande valor filosófico, já que a hegemonia do proletariado representa a transformação, a construção de uma nova sociedade, de uma nova estrutura econômica, de uma nova organização política e também de uma nova orientação ideológica e cultural. Como tal, ela não tem consequências apenas no nível material da economia ou no nível da política, mas no nível da moral, do conhecimento, da "filosofia" (Gruppi, 1980, p. 34).

Tal qual sugerem essas reflexões, a revolução proposta pelo pensamento gramsciano não se limita a reação em cadeia de grupos paramilitares contra determinado sistema, mas se refere sobretudo a uma profunda mudança cultural da sociedade. Essa ideia implica a possibilidade de se pensar uma transformação 
dos valores e das práticas sociais presentes em determinados contextos nos quais está em questão um duplo jogo entre cultura e sociedade, por meio do qual intelectuais e povo passam a confluir, de maneira homogênea, para uma nova orientação ideológica. Entretanto não devemos enxergar a hegemonia como um mero conceito. Ela é, antes de qualquer coisa, um acontecimento presente nos percursos da história.

Esse olhar atua na especificidade dos acontecimentos periféricos, pois a hegemonia é uma ferramenta responsável por agregar as classes marginalizadas pelo capitalismo a partir de determinados interesses, ou seja, deve-se partir da especificidade em direção à globalidade. Tal função exercida pela hegemonia desdobra-se num projeto de transformação da crítica, pois se efetiva no instante em que a filosofia deixa de ser algo deslocado da realidade para tornar-se parte de uma engrenagem político-prática que viabiliza a superação do conservadorismo, em nome do fortalecimento de novas concepções culturais e sociais.

A consciência de ser parte de uma certa força hegemônica (isto é, a consciência política) é a primeira fase para uma ulterior e progressiva autoconsciência, em que teoria e prática finalmente se unificam. Também a unidade da teoria e prática não é, portanto, um dado de fato mecânico, mas um devir histórico, que tem a sua fase elementar e primitiva no sentido de "distinção", de "separação", de independência, apenas instintivo, e progride até à posse real e completa de uma concepção de mundo coerente e unitária. Eis porque é de aguardar como o desenvolvimento político do conceito de hegemonia representa um grande progresso filosófico além de político-prático, porque implica e supõe uma unidade intelectual e uma ética em conformidade com uma concepção do real que superou o senso comum e se tornou, embora entre limites ainda restritos, crítica (Gramsci, 1978d, p. 2930).

A fala anteriormente descrita permite que façamos o seguinte questionamento: quando um intelectual passa a ser considerado realmente um crítico da sociedade na qual ele se encontra inserido? Com a finalidade de sublinharmos uma resposta, devemos entender primeiramente que o grande desafio pensado por Gramsci consiste no fato de que tanto a formação histórica dos intelectuais quanto o seu deslocamento do elitismo em direção ao contingente revolucionário não são um processo automático e sim algo que vai se constituindo conforme o movimento dialético da realidade.

Por exemplo, ao deter-se sobre a questão meridional, Gramsci (1997) verifica que, historicamente, no Sul da Itália, o intelectual sempre assumiu uma posição reacionária, difundindo conteúdos ideológicos sobre a classe camponesa. Ele não era um agitador, mas um elaborador de teses hegemônicas que justificavam a dominação e a exclusão do capitalismo por meio de recursos presentes na religião 
e na educação. Nesse sentido, o intelectual exercia a função de um propagandista da máquina capitalista.

Como se pode observar, a hegemonia é imprescindível para destacar as forças políticas às quais a figura do intelectual tradicional sempre permaneceu atrelada, pois enquanto se constata que o intelectual é um conservador, resta explorar outras nuances capazes de fazer emergir um novo estatuto impregnado por uma proposta crítica debitária da filosofia da práxis. Essa emergência inicia-se quando o intelectual procede uma remontagem da sua prática procurando superar os reducionismos pela profusão de novas experiências que valorizem a emancipação cultural das massas. Mas onde aconteceria essa emancipação cultural? Nas fábricas, nas escolas, no campo, enfim, onde poderia ter início esse processo de transformação? Ao examinar o papel da hegemonia no contexto da Itália, Gramsci (2007) depara-se com uma conclusão: a de que não existia naquele país nenhuma manifestação literária comprometida com a realidade nacional e que porventura fosse capaz de ter uma forte amplitude junto aos setores populares. A inexistência, pois, de uma literatura popular seria um dos maiores obstáculos para a constituição de uma educação crítica e transformadora. Nesse sentido, a formação de uma literatura popular é importantíssima para pensarse o comprometimento do intelectual em relação a seu papel no interior da sociedade. Para Gramsci (2007), o texto literário necessita de uma difusão junto aos setores populares, contribuindo, dessa forma, para a formação de uma identidade nacional.

Justamente por conta dessas características é que devemos percorrer o estatuto desse intelectual a partir da sua funcionalidade crítica e na relação direta dessa figura com a cultura. De acordo com Baratta (2009), o conceito de cultura gramsciano se refere à concepção de mundo referendada pelo materialismo histórico. Dessa maneira, ela seria a identificação refletida nos modos de vida da sociedade. Entretanto Gramsci não a fixa nos limites de um valor simbólico presente somente nos signos linguísticos ou nos ritos tradicionais de um povo, mas a percebe como um dispositivo que atua criticamente ampliando visões e significados, fazendo aparecer os elementos de reconhecimento e de soberania. Segundo essa perspectiva, a cultura seria um instrumento político capaz de conscientizar as massas contribuindo para o seu fortalecimento. Essa cultura da qual fala Gramsci (2007) deve ser encarada como o fortalecimento das massas populares. Ou seja, deve-se insistir na valorização dos produtos culturais nacionais em detrimento dos estrangeirismos e incorporaçôes feitas pelos países periféricos em relação às nações imperialistas. Outro indicativo diz respeito ao fato de que a cultura precisa ser encarada como um bloco do qual fazem parte todas as pessoas e não somente uma parcela. Ainda, segundo Baratta (2009), 
Gramsci tem uma visão de cultura universal, no sentido de que esta tem uma relação de entrelaçamento tanto com os modos de produção quanto com a política. Ou seja, ela não é estática, mas tem uma fluidez que se espalha segundo o devir e, por conseguinte, os intelectuais não devem somente participar de todas as consequências desse ato, mas, sobretudo, gerenciar esse processo.

Gramsci universaliza a cultura alargando seu âmbito e poder, colocando-a em uma relação paritária de entrelaçamento com a produção e a política, fazendo-a circular sem solução de continuidade (a não ser aquela, por sua vez decisiva, da contradição de classe) entre grupos ou estratos dominantes e subalternos. A cultura espraia-se em todas as direções além de seus confins habituais e, desse modo, arrisca-se a perder a sua identidade (Baratta, 2009, p. 53).

A maior herança deixada por Gramsci em relação ao papel da cultura na sociedade moderna consiste no fato de que, pela primeira vez no século XX, um intelectual procurou pensá-la não a partir de uma hierarquia conferindo valor a tudo aquilo que se aproximara da erudição e do sublime, mas sim como algo que diz respeito a todos. A cultura identificada com a totalidade de um território aproxima a distância entre as classes existentes.

Como consequência, os intelectuais não são mais os guardiôes da palavra, e sim personagens atuantes e presentes em um contexto maior que é o das relações sociais. Entendendo a cultura como vida social, é possível compreender-se o funcionamento dessa maquinaria a partir do que Gramsci (2007) chama de luta hegemônica. Isto é, um conjunto de ações que se efetivam na construção de uma outra ideologia referendada pela práxis. Nesse sentido, a atividade crítica consiste na compreensão do popular tomado como bloco e não somente como classe. Isso permite que se desestabilize a diferenciação entre o erudito e o popular, passando a existir um processo de formação de novos intelectuais provenientes de classes e famílias menos abastadas.

A constituição de um corpus de intelectuais tem relação direta com a instrumentalização e a difusão dessa práxis (Gramsci, 2005). Atuando em setores estratégicos, os intelectuais tornam-se agentes de transformação na sociedade não somente pela elaboração de conceitos, mas, sobretudo, pela promoção da autonomia dos blocos marginalizados pelo capitalismo. Contudo é necessário lembrar que a formação dos intelectuais somente se torna possível no instante em que passa a existir uma mediação entre eles e as massas.

Gramsci (2007) levanta também duas necessidades na formação de uma hegemonia intelectual. Por um lado, a estratégia deve assumir um compromisso de difusão e expansão dos argumentos com vistas à superação do senso comum, 
por outro, deve ser caracterizada como necessidade de emancipação política das classes oprimidas, fazendo com que os intelectuais passem a emergir das mais diversas camadas da sociedade.

Daqui se deduzem determinadas necessidades para cada movimento cultural que tende a substituir o senso comum e as velhas concepçōes do mundo em geral: 1) nunca se cansar de repetir os próprios argumentos (variando literalmente sua forma): a repetição é o maio didático mais eficaz para agir sobre a mentalidade popular; 2) trabalhar incessantemente para elevar intelectualmente sempre cada vez mais vastos estratos populares, para dar personalidade ao amorfo elemento de massa, o que significa trabalhar para suscitar elite de intelectuais de um novo tipo que surjam diretamente da massa, permanecendo, no entanto em contato com ela para se tornarem "estacas" do busto. Esta segunda necessidade, se satisfeita, é a que realmente modifica o "panorama ideológico" de uma época (Gramsci, 1978d, p. 36).

A luta em torno da superação do panorama ideológico de uma época reflete-se nessa outra perspectiva da atividade intelectual, por meio da qual a transformação é prioritariamente um ato que deve ser experienciado no próprio interior da sociedade. A estratégia assume, nesse contexto, um caráter superestrutural. Portanto a questão é deflagrar uma luta contra os sistemas ideológicos. E esse confronto sobre o qual fala Gramsci (1978d) refere-se à capacidade concreta de construção de um pensamento que atua na realidade. Ele não é, portanto, produto de uma abstração ou espontaneidade, mas sim um processo que tangencia a história por meio da ação dos sujeitos em direção ao fortalecimento das consciências críticas.

Outra questão a ser abordada diz respeito ao fato de que a batalha ideológica é uma possibilidade direta da difusão do conhecimento que é sempre transformador. No entanto, se a atividade filosófica é capaz de transformar o mundo na sua totalidade, existiria a possibilidade de concretizar-se uma linguagem universal que aproximasse os povos? Gramsci (2007) responde a essa pergunta apontando que, embora a linguagem seja inerente ao gênero humano, ela não deve ser encarada como algo unívoco e sim múltiplo, pois atua nas diferentes práticas e degraus do organismo social. Dessa maneira, a linguagem, mesmo sendo um elemento potencialmente representativo de um povo, jamais deve ser confundida como algo homogêneo, pois ela é, antes de tudo, um artefato.

Em Problemas do materialismo histórico (Gramsci, 1978d), observa-se que a grande limitação da filosofia até Marx foi enaltecer uma concepção de sujeito a partir de uma individualidade dissociada do real. É somente com a emergência da filosofia da práxis que se passa a conceber o sujeito com base em suas relações 
com a história, bem como compreender a humanidade como uma composição de diversos elementos que se alternam entre o social e o cultural.

A questão formulada por Gramsci (1978d) em relação ao estatuto do intelectual consiste no fato de que ele procurou articular conceitualmente uma transformação efetiva das suas atribuições pela mediação entre sociedade e cultura. Por conta desse aspecto, a transformação efetiva dos intelectuais é muito mais uma questão ética do que propriamente política. Posto que Gramsci (1978d) considera que todos os homens sejam intelectuais (embora nem todos exerçam essa função), percebe-se como é fundamental para a cultura moderna a libertação ideológica, no sentido de ampliar e fortalecer a presença de novos intelectuais.

A universidade, por exemplo, poderia ser outro desses espaços de produção dos novos intelectuais. Da mesma forma, os sindicatos e os partidos políticos deveriam ter em seus quadros instrumentos capazes de ampliar qualitativamente seus componentes orgânicos. Nesse sentido, os intelectuais orgânicos não limitam sua operatividade somente na instrumentalização das massas na luta contra o capitalismo. Por exemplo, quando Gramsci (2013) procura pensar a presença dos intelectuais na formação de um bloco histórico em oposição ao anacronismo social, o faz baseado em sua realidade, pois, na Itália, os três estratos sociais existentes deveriam estar unificados e não dispersos. A existência de uma grande massa camponesa, de uma pequena e média burguesia e de grandes proprietários de terra atuando em diferentes frentes não contribuía para a formação de uma unidade nacional, uma vez que, enquanto as massas não conseguiam concretizar suas necessidades, os intelectuais representavam somente os interesses das oligarquias. É contra essa condição que ele constrói seus argumentos, buscando superar essa dicotomia responsável por afastar os intelectuais dos domínios concretos da sociedade.

Ocorre que, na esteira desse processo, encontra-se uma problematização em relação aos próprios intelectuais críticos. De um lado, existiriam os intelectuais acadêmicos que geralmente associam o marxismo a concepçôes filosóficas com base num diálogo com outras correntes idealistas. Do outro lado, intelectuais revolucionários que fazem da prática sua estratégia na busca pela revolução. Enquanto os primeiros constroem reflexões comprometidas com os interesses da classe dominante, os segundos permanecem atrelados à crença de que a transformação efetiva da realidade somente é possível por meio da apropriação dos modos de produção. 
A filosofia da práxis foi um momento da cultura moderna; numa certa medida, determinou ou fecundou algumas de suas correntes. $\mathrm{O}$ estudo deste fato, muito importante e significativo, foi negligenciado ou mesmo ignorado pelos chamados ortodoxos, e pela seguinte razão: a de que a combinação filosófica mais relevante aconteceu entre a filosofia da práxis e diversas tendências idealistas, o que aos chamados ortodoxos, ligados essencialmente à corrente particular da cultura do último quarto do século passado (positivismo, cientificismo), pareceu um contrassenso, se não uma jogada de charlatães (no entanto, no ensaio de Plekhanov, Questóes Fundamentais, existe alguma referência a este fato, mas só de passagem e sem qualquer tentativa de explicação crítica). Por isso, parece necessário revalorizar a formulação do problema assim como foi tentada por Antonio Labriola. O que aconteceu foi isto: a filosofia da práxis sofreu realmente uma dupla revisão, isto é, foi subsumida numa dupla combinação filosófica. Por uma parte, alguns de seus elementos, de modo explícito ou implícito, foram absorvidos e incorporados por algumas correntes idealistas (basta citar Croce, Gentile, Sorel, o próprio Bergson, o pragmatismo); por outra, os chamados ortodoxos, preocupados em encontrar uma filosofia que fosse, segundo o seu ponto de vista muito restrito, mais compreensiva do que uma "simples" interpretação da história, acreditaram-se ortodoxos identificando-a fundamentalmente no materialismo tradicional. Uma outra corrente voltou ao kantismo (e se podem citar, além do professor Max Adler, os dois professores italianos Alfredo Pogi e Adelchi Baratono). Pode-se observar, em geral, que as correntes que tentaram combinações da filosofia da práxis com tendências idealistas são, numa parte muito grande, de intelectuais "puros", ao passo que a corrente que constituiu a ortodoxia era de personalidades intelectuais mais acentuadamente dedicadas à atividade prática e, portanto, mais ligadas (por laços mais ou menos extrínsecos) às grandes massas populares (o que, de resto, não impediu a maioria de fazer piruetas não destituídas de importância histórica-política) (Gramsci, 2007, pp. 31-32).

A superação desses extremismos depende de dois fatores: em primeiro lugar, o combate às ideologias e, em segundo lugar, o desenvolvimento de estratégias que facilitem a promoção da autonomia. Como se pode observar, a formação de um bloco histórico depende da intensificação de práticas que desembaraçam os intelectuais de vícios e limitações, pois é a junção das forças políticas semelhantes que forma a base de constituição de qualquer organismo.

Gramsci (2013) defende a tese de que, para se compreender efetivamente o nível de articulação entre as forças existentes da sociedade, os intelectuais precisam inferir uma profunda análise tanto da ciência quanto da política. Por ciência, ele refere-se não ao estudo sobre a teoria do conhecimento, mas sim aos diversos níveis estruturais compostos pelas ideologias existentes. Já a política seria o conjunto de estratos que formam a prática presente no contexto da administração orgânica. A conclusão obtida diz respeito à limitação da ciência na articulação precisa dos critérios hierárquicos presentes nas relações ideológicas. Da mesma maneira, falta à política apontar a relação entre o que é orgânico e o que é ocasional. $\mathrm{O}$ enfrentamento a esses dois problemas é o maior desafio posto aos intelectuais. Certamente que tal batalha está inscrita predominantemente 
nos domínios da crítica política, porém ela pode ser associada à atividade ética referendada pelas noçôes de engajamento e de compromisso social.

No centro de todos esses conceitos envolvidos pela filosofia da práxis como hegemonia, ideologia e sociedade política, circula o problema dos intelectuais, pois são eles que ou garantem a exploração ou procuram difundir novos quadros orgânicos. Suas palavras e suas ações estão sempre em relação a algo ou alguém. Isso nos permite afirmar que encontramos ao percorrer no conjunto de textos gramscianos um estatuto do intelectual voltado para o problema interno da superestrutura. Um estatuto de intelectual construído não como uma categoria alheia à realidade, mas como um sujeito que está imerso no jogo das ideologias e que milita no sentido de produzir a transformação social.

De acordo com Souza (2009), é impossível realizar qualquer reflexão acerca do estatuto do intelectual orgânico sem que se explore detalhadamente o valor das ideologias no interior da sociedade, ressaltando o processo de organização dos intelectuais na estrutura social. Nesse sentido, o desafio consiste em interpelar criticamente a cultura e a sociedade sobre o valor de suas práticas, e a que elas estão comprometidas. A organização dos intelectuais depende exclusivamente do olhar praticado por eles, ou seja, se determinado intelectual está comprometido com antigas práticas, ele é um conservador; entretanto, se ele é um crítico da superestrutura, ele é orgânico.

Esse estatuto é desenhado em Os intelectuais e a formação da cultura (Gramsci, 1997). Na realidade, esse texto é um diagnóstico para uma leitura histórica e cultural da sociedade moderna no início do século XX. Enquanto que os intelectuais tradicionais estão ligados a setores ruralistas e eclesiásticos, os intelectuais orgânicos estão ligados às artes e a práticas de modernização. De todo esse apanhado, entendemos que existe um confronto ideológico entre essas duas categorias. A questão consiste em problematizar o caminho a ser seguido; ou o conservadorismo ou a emancipação cultural das massas.

Em especial, o capítulo dedicado à formação dos intelectuais merece uma atenção mais detalhada por conter traços importantes na conceituação dessas diferenças.

Os intelectuais são um grupo social autônomo e independente ou todos os grupos sociais têm as suas próprias categorias de intelectuais especializados? O problema é complexo pelas diversas formas que assumiu até agora o processo histórico real da formação das diferentes categorias intelectuais (Gramsci, 2013, p. 3).

Essa pergunta aponta para a necessidade de constituir-se uma análise em torno do processo histórico da formação das diversas categorias de intelectuais cujas 
duas mais importantes são: em primeiro lugar, os intelectuais que representam a continuidade histórica e, em segundo lugar, os intelectuais orgânicos como figuras emergentes da modernidade e do capitalismo.

O intelectual tradicional está associado principalmente à Igreja, isso porque o clero monopolizou, durante muitos anos, o acesso ao conhecimento. Esse monopólio se converteu na existência dos primeiros intelectuais totalmente comprometidos com os interesses da Igreja pela difusão ideológica e a revelação da Sagrada Escritura. É somente a partir das grandes navegações que começaram a proliferar novas vozes de enfrentamento do poder eclesiástico.

As reflexões filosóficas como as de Descartes, por exemplo, instituíram um deslocamento no que se referia à superestrutura do poder e do saber, passandose da ideologia clerical para uma ideologia ligada aos interesses da monarquia. É sempre importante lembrar que o movimento histórico apresentado por Gramsci não deve ser entendido como uma linearidade de acontecimentos que deveriam conduzir a formação de um bloco entre os intelectuais. Pelo contrário, esse movimento foi absolutamente difuso e disperso. Ao debruçar-se sobre o pensamento ocidental por meio desse olhar e reconhecer na base dessas reflexões matrizes totalmente idealistas, Gramsci está interessado em mostrar que os intelectuais conservadores são responsáveis por instituir uma representação da realidade, negando, dessa maneira, o papel conflituoso das forças ideológicas.

Já o intelectual orgânico está inscrito diretamente no regime econômico, social e político do capitalismo. Nesse sistema, a atividade intelectual está associada à organização efetiva da mercadoria e dos modos de produção. Nesse sentido, ele é um organizador da sociedade em geral, e tal organização somente se torna possível porque o intelectual vale-se de um determinado conhecimento. Quando Gramsci (2013) fala no intelectual orgânico, está designando uma nova compreensão para essa figura a partir de um estatuto que não deve mais ser confundido com as suas clássicas atribuições de grande orador ou de mestre da escrita, mas sim de alguém que efetivamente desenvolve suas atividades no cotidiano da sociedade, uma vez que ele é, ao mesmo tempo, produto e produtor das questóes culturais. Assim, os grandes empresários possibilitam o aparecimento do economista e do administrador que devem agir segundo os interesses desse bloco. Da mesma forma, o operariado possibilita o aparecimento do sindicalista ou do professor engajado, por exemplo, responsáveis por atuarem na direção do compromisso com o socialismo e a melhoria das condições de vida das classes marginalizadas pelo capitalismo.

A proposta do intelectual orgânico implica um questionamento essencial sobre esse problema: qual o sentido da atividade intelectual no século XX? 
Vejamos como Gramsci (2013) aborda essa questão:

Pode encontrar-se um critério unânime para caracterizar as diversas e díspares atividades intelectuais, distinguindo-as a tempo e na essência das correspondentes a outros grupos sociais? Parece-me que o erro de método mais corrente é ter-se procurado neste modo de ver o que é diferente no plano intrínseco do trabalho intelectual, em vez de situá-lo no conjunto do sistema de relaçôes em que eles - e, por conseguinte, os grupos que os personificam acabam por se unir ao complexo geral das relaçóes sociais (p. 6).

O que está em jogo nesse conjunto de problematizações é o fato de que a maioria dos estudos acerca do intelectual acaba por situar todas as reflexões com base num sistema ideológico que gira sobre si. Isto é, como se todas as reflexões partissem da cabeça de um sujeito altamente capaz de interpretar e transmitir o seu conhecimento às demais pessoas. Na opinião de Gramsci, perde-se de vista a obviedade de que, no contexto da modernidade, todas as atividades laborais exigem um determinado conhecimento. Contudo essa característica de que todos os homens são intelectuais, própria da modernidade, não inviabiliza a existência de uma função para o intelectual. Desse modo, em uma nação onde não haja uma justa distribuição de renda nem acesso a uma educação pública de qualidade, é um dever do intelectual abordar esses assuntos no seu cotidiano, seja ele um professor, um artista, um escritor ou mesmo um operário.

Outra questão relevante em relação ao papel do intelectual orgânico na modernidade efetiva-se no fato de que, segundo o pensamento gramsciano, uma vez que o homem se apropria da natureza com a intenção de dominá-la e transformá-la, não existe o menor sentido em falar da atividade intelectual a partir da dissociação dessa atividade com o trabalho manual. Na realidade, Gramsci (2013) chega a ser provocativo ao ressaltar que é impossível separar o Homo faber do Homo sapiens. O problema consiste em situar a função dos intelectuais na sociedade transmitindo a ideia de que toda prática, para ser realmente crítica, deve estar atrelada a uma determinada concepção de mundo. A concepção de intelectual defendida por essa perspectiva refere-se ao exercício de uma prática que toma a vida como alvo direto dos seus questionamentos. Enquanto o intelectual tradicional atua sempre segundo os critérios da abstração e da teleologia, pensando no futuro como possibilidade utópica, o intelectual orgânico exerce seu papel na organização da cultura com base na realidade e no contexto ao qual ele pertence.

Nesse sentido, a ampliação do quadro de intelectuais depende também da elaboração de estratégias que levem em conta a formação de uma identidade nacional popular. A educação ocupa um lugar central nessa reflexão, por ser 
um dos núcleos da formação intelectual. Se determinado Estado privilegia, na sua política educacional, o ensino técnico e instrumental, valoriza somente uma parte do conjunto intelectual necessário à emancipação financeira do indivíduo, deixando de lado a emancipação política.

Conforme pode-se observar, a leitura de Gramsci em relação ao intelectual orgânico infere um retrato dessa figura no contexto do capitalismo, pois, como já foi dito, nesse sistema, qualquer sujeito ligado à produção ou à difusão do conhecimento é um intelectual. Justamente por fazer parte desse processo é que o pensamento de Gramsci permanece atual, principalmente no que corresponde à luta contra o elitismo cultural. Todos os ensinamentos presentes nos seus textos indicam a possibilidade de destituir o intelectual de seu sagrado ofício e lançá-lo no terreno das profanaçôes, onde ele é obrigado a desarticular práticas e conceitos obsoletos e imergir na realidade, sempre se implicando e comprometendo-se com aquilo que fala. Para Said (2000):

A proliferação dos intelectuais atingiu mesmo um grande número de áreas em que os intelectuais - possivelmente seguindo as sugestōes pioneiras de Gramsci em Notas da Prisão, que viam, quase pela primeira vez, os intelectuais, e não as classes sociais, como pivôs dos avanços da sociedade moderna - se tornaram o objeto de estudo. Basta colocar as palavras "de" e "e" ao lado da palavra "intelectuais" e, quase de imediato, surge diante dos nossos olhos uma biblioteca inteira de estudos sobre intelectuais, bastante intimidadora na sua amplitude e minuciosamente detalhada no seu enfoque. Estão disponíveis milhares de diferentes histórias e sociologias de intelectuais, bem como relatos intermináveis sobre os intelectuais e o nacionalismo, e o poder, e a tradição, e a revolução, e por aí fora. Cada região do mundo produziu os seus intelectuais e cada uma dessas formaçóes é debatida e discutida com uma paixão ardente. Não houve nenhuma grande revolução na história moderna sem intelectuais; como nunca houve nenhum movimento contrarrevolucionário sem intelectuais. Os intelectuais têm sido os pais e as mães dos movimentos e, claro, os seus filhos e filhas e até sobrinhos e sobrinhas. Há o perigo de a figura ou imagem do intelectual desaparecer num mar de pormenores, e de o intelectual se transformar em apenas mais um profissional ou num número de uma tendência social (pp. 27-28).

Essas palavras emblemáticas apontam para uma onipresença do intelectual no cotidiano da sociedade capitalista do início do século XX, sendo-nos impossível deixar de debater sobre essa figura a partir de um olhar provocativo que o pensamento gramsciano propicia, principalmente no que corresponde ao fortalecimento de uma cultura pluralista, pois sua efervescência seria a porta de entrada para o nascimento do intelectual orgânico. Nesse sentido, a história da cultura apresenta-se como uma leitura da realidade de uma perspectiva crítica que encontra na filosofia da práxis a síntese dialética da manifestação cultural. Ocorre que, como muitos intelectuais provenientes do marxismo, embora sejam 
engajados, permaneçam atrelados a uma concepção elitista e burguesa de cultura. Encontramos um exemplo proeminente desse modelo de intelectual nos estudos da Escola de Frankfurt e, mais especificamente, em Adorno (2002). A questão levantada por Gramsci consiste na tarefa de percebermos o intelectual orgânico como um personagem e a cultura como um processo sempre em expansão. Assim, o intelectual orgânico como raison d'être é o sujeito que, atrelado ao sistema cultural, procura pensar questóes polêmicas e dirigir uma prática que esteja necessariamente atrelada a problemas sociais modernos. Esse personagem está preso na organização da cultura agindo sempre em relação, e esse agir se efetiva numa proposta de transformação histórica na qual as velhas ortodoxias cedem espaço para novas inquietações e dilemas. 


\section{REFERÊNCIAS}

Adorno, T. W. (2002). Indústria cultural e sociedade. Rio de Janeiro: Paz e Terra.

Baratta, G. (2009). Cultura para todos. Revista Cult, 12(141), 77-80.

Bianchi, Á. (2009). Realismo e política. Revista Cult, 12(141), 85-90.

Gramsci, A. (1978a). Alguns problemas para o estudo da filosofia da práxis. In A. Gramsci, Obras escolhidas. (pp. 67-146). São Paulo: Martins Fontes.

Gramsci, A. (1978b). O problema da revolução. In A. Gramsci, Obras escolhidas. (pp. 237-269). São Paulo: Martins Fontes.

Gramsci, A. (1978c). Problemas de História e de Política. In A. Gramsci, Obras escolhidas. (pp. 273-340). São Paulo: Martins Fontes.

Gramsci, A. (1978d). Problemas do materialismo histórico. In A. Gramsci, Obras escolhidas. (pp. 19-66). São Paulo: Martins Fontes.

Gramsci, A. (1997). Os intelectuais e a organização da cultura. Rio de Janeiro: Civilização Brasileira.

Gramsci, A. (2004). Escritos politicos: 1919-1920. (Vol. 1). Rio de Janeiro: Civilização Brasileira.

Gramsci, A. (2005). Passado e presente. In E. Sader (Org.), Gramsci, poder, política e partido. (pp. 15-45). São Paulo: Expressão Popular.

Gramsci, A. (2007). Cadernos do cárcere: temas de cultura, ação católica, americanismo e fordismo. (Vol. 4). Rio de Janeiro: Civilização Brasileira.

Gramsci, A. (2013). A formação dos intelectuais. S. Ferreira (Trad.). Rio de Janeiro: Achiamé.

Gruppi, L. (1980). O conceito de hegemonia em Gramsci. Rio de Janeiro: Graal.

Marx, K. (1982). Contribuição à crítica da economia política. Lisboa: Difel.

Said, E. (2000). Representaçôes do intelectual. Lisboa: Colibri.

Secco, L. (2009). Por um novo marxismo. Revista Cult, 12(141), 72-75.

Souza, A.R. (2009). O Estado moderno e o papel dos intelectuais em Gramsci. In Anais, 4 Congresso Internacional de História da UEM. (pp. 1965-1976). 
Maringá. Maringá: Programa de Pós-Graduação em História, Universidade Estadual de Maringá. Recuperado a partir de http://www.pph.uem.br/cih/ anais/trabalho.php?tid $=564$ 